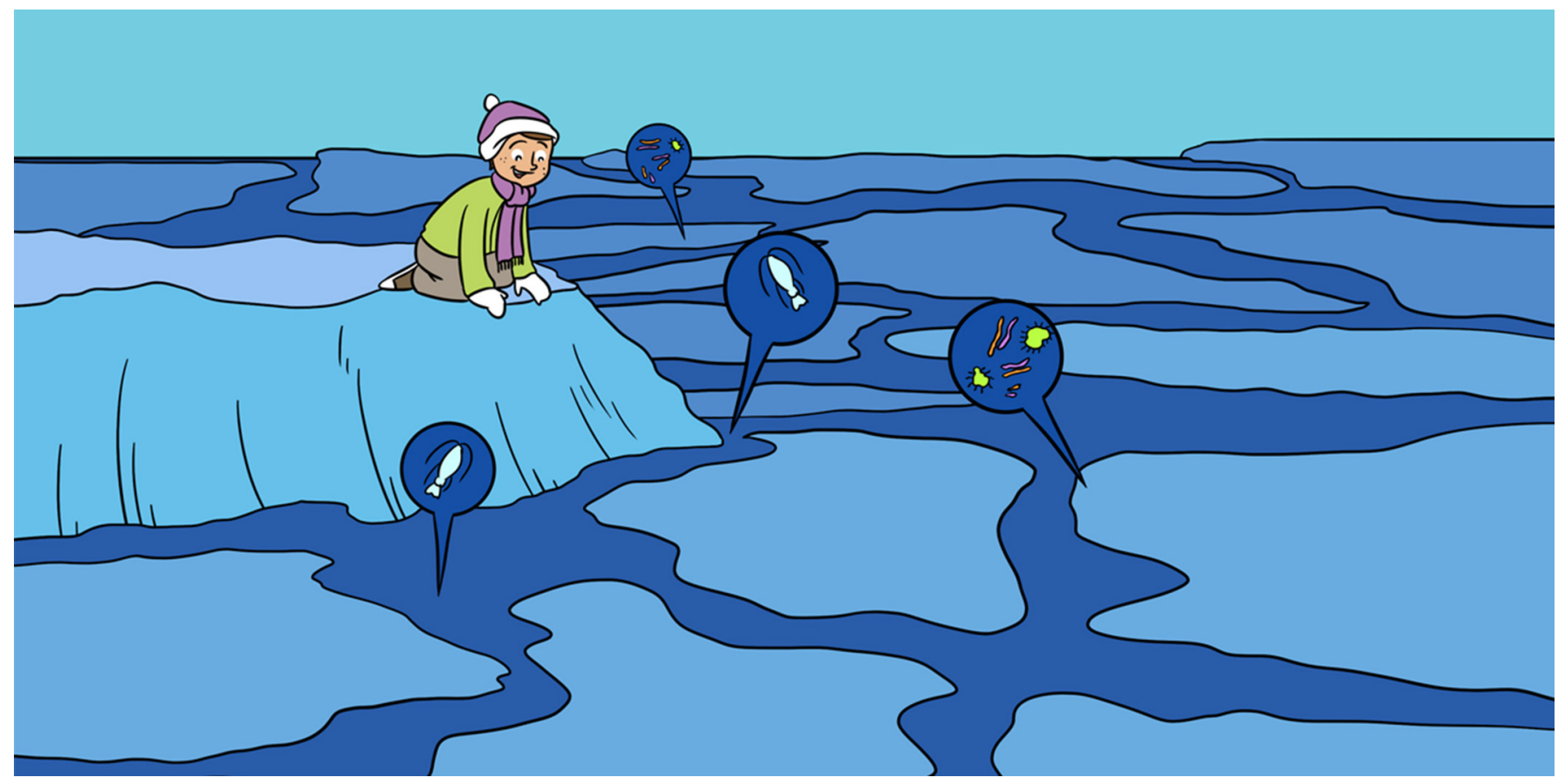

\title{
LIFE INSIDE AND UNDER FROZEN SEAWATER
}

\section{David N. Thomas ${ }^{1 *}$ and Hermanni Kaartokallio ${ }^{2}$}

${ }^{1}$ School of Ocean Sciences, Bangor University, Bangor, United Kingdom

${ }^{2}$ Finnish Environment Institute (SYKE), Marine Research Centre, Helsinki, Finland

YOUNG REVIEWERS:

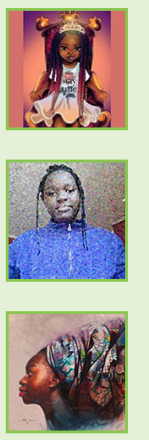

PRICE

AGE: 12

PRINCESS

AGE: 14

PROVIDENCE

AGE: 8
Seawater freezes below $-2.0^{\circ} \mathrm{C}$ and therefore ice covers vast areas of the polar oceans for part of every year. First, ice crystals float to surface; then ice floes form to create a frozen landscape on the ocean surface. This pack ice moves with wind and currents and can form huge piles of ice rubble or expose open water when ice floes move apart. When seawater freezes, salty brines are trapped in a network of tiny channels and pockets throughout the ice. This network is a living place for microscopic ice organisms like bacteria, algae, tiny animals, small worms, and crustaceans. Ice algae grow best on the underside of ice where animals can feed on them. Sea ice is an important site of food production for many organisms in the polar oceans and seas and when the ice melts, it can also support life on the sea floor, which can be thousands of meters below.

\section{SEA ICE FORMATION}

Freshwater from a lake, river, bird bath, or tap freezes at $0^{\circ} \mathrm{C}$. If salt is added to water, the freezing point goes down. This means that 
Figure 1

When ice begins to form, vast areas of what is called grease ice form slicks on the ocean surface.

\section{SALINITY}

The salt content of water is called salinity-water with no salt has a salinity of 0 , seawater with $35 \mathrm{~g}$ of salt per liter has a salinity of 35 and salty brines with 200.

\section{PACK ICE}

Sea ice that is moved around by ocean currents and wind.

\section{ICE FLOE}

A continuous area of sea ice. These can vary in area from a few $\mathrm{m}^{2}$ through to floes several $\mathrm{km}^{2}$.

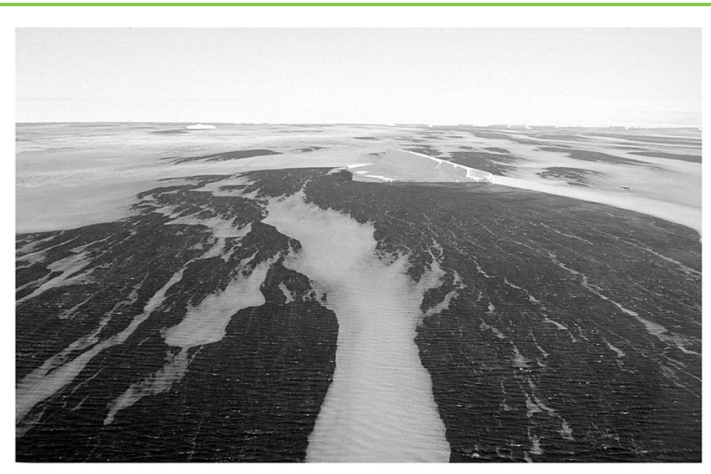

Figure 1

seawater, which generally has a salinity (salt content) of $30-35 \mathrm{~g}$ of salt per liter, does not start to freeze until around $-2.0^{\circ} \mathrm{C}$.

In the polar regions during autumn (August/September in the Arctic, March/April in the Antarctic), rapidly falling air temperatures cool the surface waters below the freezing point. Surface layers of the oceans, up to several hundred meters below the surface, are constantly being mixed by wind and water motion. When the freezing starts, tiny ice crystals begin to appear everywhere in the surface water layer and float to the surface. This is the beginning of what is called pack ice: the frozen realms that have captured the imagination of explorers and adventurers for hundreds of years [1].

As more and more ice crystals accumulate on the surface of the water, they form a layer with the consistency of a thin porridge. The "porridge-ice" is then moved around by wind to form huge slicks of ice crystals that can cover many $\mathrm{km}^{2}$ (Figure 1). On the surface, the ice is in contact with the cold air and the crystals freeze together to form a more rigid ice layer. When the cold seeps through the ice, the ice grows mainly from bottom and freezes the seawater that is in contact with the bottom of the ice layer. Within a few weeks, the ice can be more than $1 \mathrm{~m}$ thick.

The ocean waters are constantly moving, and ice is broken into large pieces called ice floes, which float on the ocean surface. Ice floes can range from a few meters to over $100 \mathrm{~m}$ wide. Many floes can freeze together to form continuous ice floes up to several kilometers wide. These in turn can then break up again into smaller floes as the ice moves with currents, tides, and wind. When wind and currents force ice floes against each other, they can pile on top of each other and form huge ice piles called ridges (Figure 2B). Also, the wind can pull ice floes apart to expose open stretches of water called leads. The constantly moving ice creates a landscape (or a frozen-scape) that changes day by day and even hour by hour (Figures 2A,B). 


\section{Figure 2}

The pack ice of the Arctic and Antarctic Oceans is a varied environment that can be quite hostile to life. (A) Cold windswept landscapes which from the surface seem devoid of life. (B) Big slabs of ice pushed into the air to form ridges as ice floes colide.

\section{BRINE}

A solution with high concentrations of salt.

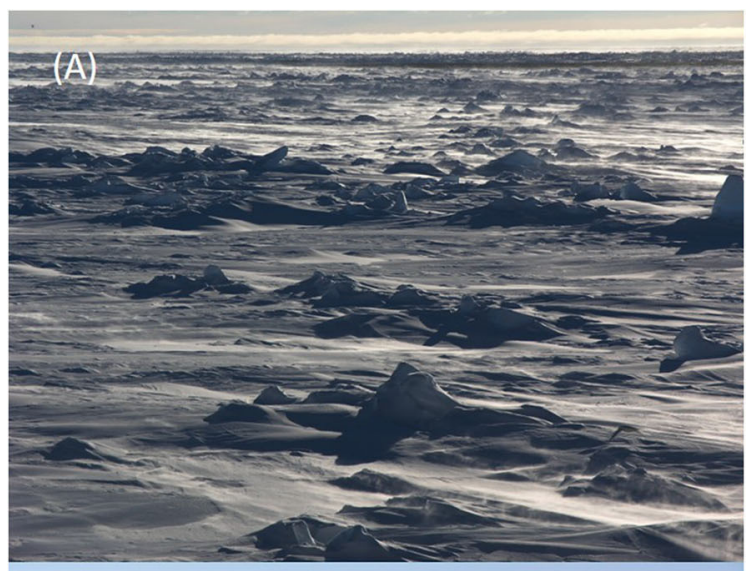

(B)

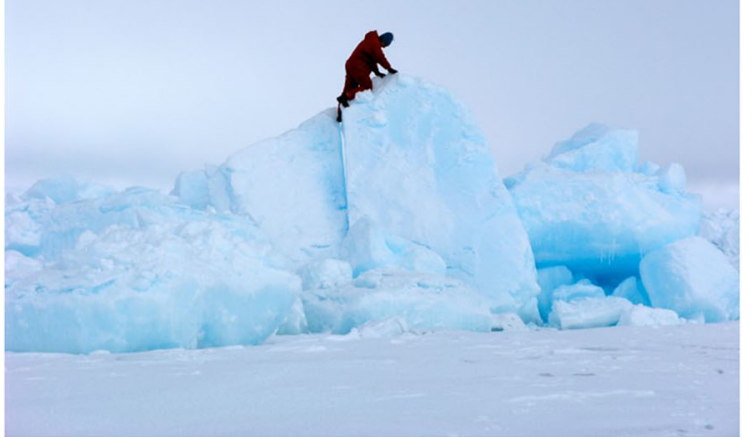

Figure 2

\section{INSIDE SEA ICE}

Growing ice crystals are pure water and do not contain any salts or other compounds that are normally dissolved in the seawater. Therefore, as the ice crystals freeze together to form more solid ice, all the dissolved substances in the seawater are forced out, creating a very salty liquid called a brine. This brine collects in a network of very small channels, called brine channels, and small holes called pores within the growing ice. The best comparison is to think of Swiss cheese or a sponge, where the solids are ice and the holes are filled with a salty brine.

As ice gets colder, the size of the brine channels and pores gets smaller and the salinity of the brines within them increases. The ice at the bottom of an ice floe will be at the freezing point of seawater (around $-2^{\circ} \mathrm{C}$ ) and the ice at the top of the floe will be close to the air temperature. As air temperatures during polar winters can be as low as $-30^{\circ} \mathrm{C}$, there will be a temperature gradient between the top of the ice near the air and the bottom of the ice. Because of this gradient, the colder ice at the top of an ice floe will have smaller brine channels and pores filled with higher salinity brines than those that are found lower in the ice. 
Figure 3

(A) Rich accumulations of living things stain the underside of ice floes brown. (B) Brown ice sample taken with $10 \mathrm{~cm}$ diameter ice-corer. (C) Microscope image of sea-ice diatoms, magnified about $1,000 \times$ (image $\mathrm{J}$. Stefels).

\section{DIATOMS}

Unicellular algae common in seawater and freshwaters. They are characterized by being encased in tough outer covering made of silicate (like glass).

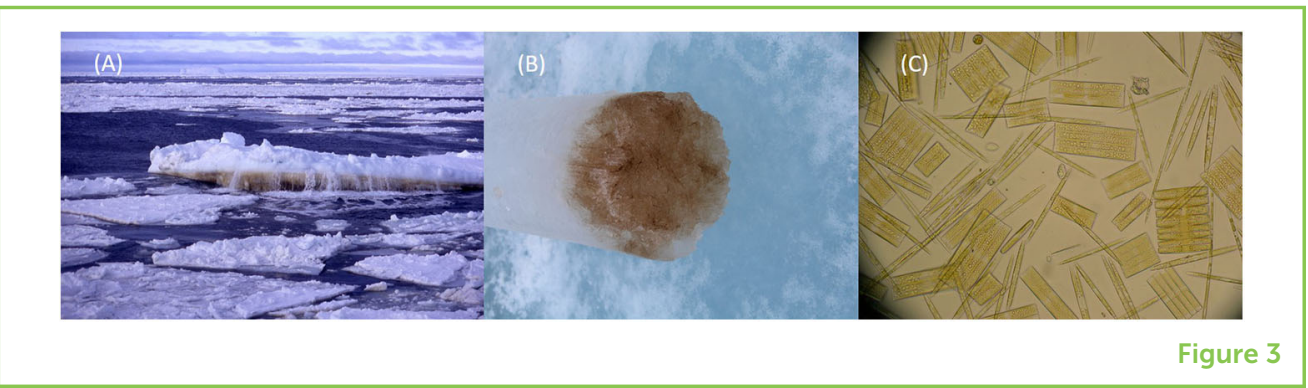

\section{LIVING IN THE ICE}

In autumn, as the ice crystals float upwards through the water, they catch particles between themselves, collecting the particles into the ice porridge that is forming on the ocean surface. All kinds of small things floating in the water can be caught by the ice crystals. These can be micro-plastics or sediments, as well as living microscopic creatures like bacteria, microalgae, larvae, and small crustaceans. Basically, anything that sticks into the ice crystals and cannot swim away can be moved from the open water into the ice.

Organisms that can live in the ice must be able to survive freezing temperatures, but they also must cope with high and ever-changing brine salinities. Most importantly, they need to be small enough to avoid getting stuck and frozen within the small brine channels. This is not such a problem at temperatures warmer than $-10^{\circ} \mathrm{C}$, but at colder ice temperatures, around $-20^{\circ} \mathrm{C}$, the spaces between ice crystals are so small that there is space for only the smallest of bacteria [2].

At the bottom of ice floes close to the seawater, the ice can be packed with organisms. In fact, there is so much life that sometimes the ice is colored yellow or a rich coffee color (Figures $3 \mathrm{~A}, \mathrm{~B}$ ). The most common creatures in the ice bottom are tiny algae. There are also many bacteria that live in the slimes produced by ice algae and the remains of dead organisms. A group of algae called diatoms are the most common group of ice algae (Figure $3 \mathrm{C}$ ). Diatoms grow inside hard shells that look like tiny, ornately patterned boxes made of silicate, which is like a tough glass.

Algae, like plants, use photosynthesis to capture light energy to grow. It is quite dark at the bottom of an ice floe, especially if it is covered in a layer of snow. Therefore, those algae that grow well in sea ice are good at growing in low light. To do this, they must have more of the chemical pigments needed to trap the light that fuels photosynthesis. It is the high amount of these light-trapping pigments that results in the color of the ice.

To survive the low temperatures and high salinities in the brines, the algae must adjust their internal environment to balance the changes in the external environment, by increasing or decreasing some chemicals 
within their cells. Some of these chemicals can regulate the pressure inside the algal cells, so they do not shrink or explode from differences in salinity. Other chemicals can also act as anti-freeze agents. Many of the algae and bacteria that thrive in the ice cover the outside of their cells with gel-like coatings. These coatings protect the cells from ice crystal damage and the most drastic changes in temperature and salinity.

\section{SEA-ICE ALGAE CAN PROVIDE FOOD FOR MANY ORGANISMS}

The high numbers of algae and bacteria in ice create rich feeding grounds for other organisms that eat them. Crustacean copepods are small shrimp-like creatures that can be found in high numbers in the lower, "warmer" layers of the ice, where they eat ice algae and bacteria. In colder parts of the ice where brine channels are smaller, more flexible-bodied animals, such as flat worms called turbellarians, round worms called nematodes, and simple organisms called ciliates can live in high numbers. These animals can shrink in high salinity water and swell in lower salinity water, which helps them move through the brine channel system.

The lower layers of an ice floe are generally where most of the living things can be found (Figure 3A). This in turn draws larger organisms to the underside of the ice, where they can feed on organisms growing between large ice crystals hanging from the bottom of the ice, like a bright brown, upside-down meadow glowing from the light above. Such organisms are many and varied, including sea slugs (nudibranchs), larger crustaceans, such as krill and even fish. The ice is a very important source of food for these larger animals, especially in winter when there is little to no food in the dark waters below. The small algae-eating animals under the sea ice are in turn food for even larger animals, such as seals, penguins, and other marine birds. Sea-ice algae growth is therefore very important for much of the life in pack ice-covered waters.

Sea-ice algae can entirely cover the undersides of ice floes in spring and early summer (Figure 3). Some species even form strands and clumps hanging from the underside of the ice. Sooner or later, if not eaten, this rich food supply drops from the ice and sinks into the water. It can even reach the deep-sea floor thousands of meters below the ocean surface. On the seafloor, it is food for large, mobile animals like sea cucumbers and brittle stars [3].

\section{SEA-ICE ECOSYSTEMS ARE VULNERABLE}

Although sea ice is an important living space for organisms in winter, it is only a short-lived one. In spring and early summer, as air and 
water temperatures increase, the ice starts to melt. This releases all the organisms living inside it back into the water, where they stay until the next cycle of freezing starts the next autumn. Even though the sea ice comes and goes, the huge areas covered by sea ice in the autumn and winter (Arctic 15 million $\mathrm{km}^{2}$ and Antarctic 22 million $\mathrm{km}^{2}$ ) make it one of the largest biomes on the planet. The area covered by sea ice on Earth is as large as the area covered by savannahs or crop lands. In both the Arctic and the Antarctic, we are already seeing that the changing climate is greatly altering the timing of when sea ice forms and melts, as well as the nature of that ice. Recognizing the importance of the life that thrives in and on the ice is critical for our understanding of what these climate changes will mean for entire ecosystems that are associated with sea ice.

\section{REFERENCES}

1. Glessmer, M. 2019. How does ice form in the sea? Front Young Minds 7:79. doi: 10.3389/frym.2019.00079

2. Thomas, D. N., and Dieckmann, G. S. 2002. Antarctic sea ice-a habitat for extremophiles. Science 295:641-4. doi: 10.1126/science.1063391

3. Boetius, A., Albrecht, S., Bakker, K., Bienhold, C., Felden, J., Fernández-Méndez, M., et al. 2013. Export of algal biomass from the melting Arctic sea ice. Science 339:1430-2. doi: 10.1126/science.1231346

SUBMITTED: 23 February 2020; ACCEPTED: 13 August 2020;

PUBLISHED ONLINE: 09 September 2020.

EDITED BY: Kirsty C. Crocket, University of Edinburgh, United Kingdom

CITATION: Thomas DN and Kaartokallio H (2020) Life Inside and Under Frozen Seawater. Front. Young Minds 8:537335. doi: 10.3389/frym.2020.537335

CONFLICT OF INTEREST: The authors declare that the research was conducted in the absence of any commercial or financial relationships that could be construed as a potential conflict of interest.

COPYRIGHT @ 2020 Thomas and Kaartokallio. This is an open-access article distributed under the terms of the Creative Commons Attribution License (CC BY). The use, distribution or reproduction in other forums is permitted, provided the original author(s) and the copyright owner(s) are credited and that the original publication in this journal is cited, in accordance with accepted academic practice. No use, distribution or reproduction is permitted which does not comply with these terms. 


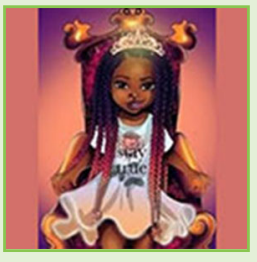

\section{YOUNG REVIEWERS}

\section{PRICE, AGE: 12}

Price loves making up stories and has also written a book (Ms. Wasteson and the waste empire). She enjoys gymnastics, athletics, volleyball, and basketball. She is brave and bouncy. Price also enjoys quality time with family and is very creative. At her school, she is part of a "green team" that works to protect the environment. She likes debating and has a passion to study and become an activist against social injustices.
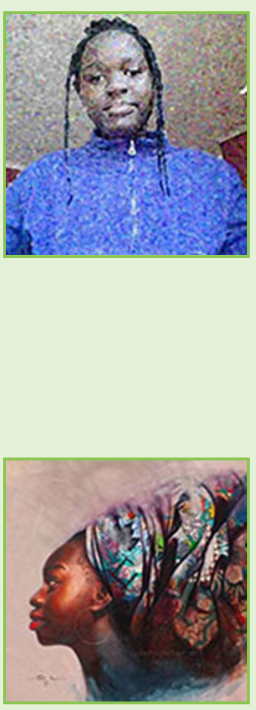

\section{PRINCESS, AGE: 14}

Princess has many ideas and goals and is passionate about helping others to be better. She is a deep thinker while solving problems. Princess is funny, sporty, jumpy, and a kind person, who loves exploring to find solutions. She is creative, narrative, and likes writing. Princess wrote a book titled "Sarah and the waste center." She loves learning new things. She is into volleyball, music, band, art, and digital photography. Her purpose is to learn more about science, and to improve her writing and editing skills.

\section{PROVIDENCE, AGE: 8}

Providence is the youngest amongst her three sisters. She is playful and bouncy. Providence is curious, talkative, and likes asking many funny questions, that leaves others laughing. She loves making new friends and traveling. Providence loves science experiments. During this process, she may destroy, repair or recycle some household items. As part of this adventure, Providence repaired a spoilt speaker. But after weeks of action, she modeled the speaker wires into skipping ropes. She is passionate over music and sports.

\section{AUTHORS}
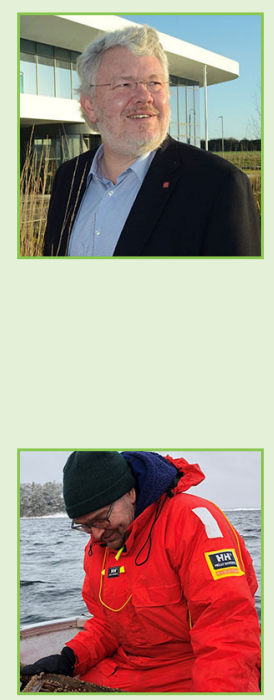

\section{DAVID N. THOMAS}

David N. Thomas is a Professor of Marine Biology at Bangor University, U.K. His research spans a wide range of subjects around the ecology and physiology of marine seaweeds and phytoplankton. His work is very much at the interface of biology and chemistry in marine, estuarine, and river systems. He has extensive experience studying the life that lives within, on, and below frozen pack ice in the Antarctic and Arctic Oceans and Baltic Sea. *d.thomasabangor.ac.uk; david.thomas@helsinki.fi

\section{HERMANNI KAARTOKALLIO}

Hermanni Kaartokallio is a Senior Research Scientist at the Finnish Environment Institute (SYKE) Marine Research Centre, Helsinki, Finland. His research is focused on marine bacteria, especially in sea ice and other cold environments in the Baltic Sea and Arctic. This includes bacterial activity, production, processes, communities, and interactions with their environment. He studies bacteria in waters as they pass from land through rivers to coastal waters and how bacteria survive in cold marine environments. 